DOI: $10.1590 / 1089-6891 v 18 \mathrm{e}-37633$

ZOOTECNIA

\title{
PERFORMANCE OF BROILERS FED DIFFERENT DIETARY CHOLINE SOURCES AND LEVELS
}

\section{DESEMPENHO DE FRANGOS DE CORTE SUPLEMENTADOS COM DIFERENTES FONTES E NÍVEIS DE COLINA NA DIETA}

\author{
Giovani Farina ${ }^{1^{*}}$ \\ Alexandre de Mello Kessler ${ }^{1}$ \\ Patrícia Diniz Ebling ${ }^{1}$ \\ Fábio Ritter Marx ${ }^{1}$ \\ Ricardo César² \\ Andréa Machado Leal Ribeiro ${ }^{1}$ \\ 1Universidade Federal do Rio Grande do Sul, Porto Alegre, RS, Brazil \\ ${ }^{2}$ Technofeed Ltda., Vinhedo, SP, Brazil \\ "Corresponding author - giovani.farina@ufrgs.br
}

\begin{abstract}
Two experiments were carried out to evaluate the bioequivalence of a commercial phosphatidylcholine source (Biocholine ${ }^{\mathrm{TM}}$ ) as an alternative to choline chloride and the choline requirements of broilers of a fast-growth strain. In Experiment I, 672 broilers were fed four Biocholine $^{\mathrm{TM}}$ levels $(0,100,200$, or $300 \mathrm{mg} / \mathrm{kg})$ and three choline levels $(200,400$, or $600 \mathrm{mg} / \mathrm{kg})$ supplied as choline chloride between 4 and 28 days (d) of age. In Experiment II, 462 broilers received diets supplemented with $0,200,400,600$ or $800 \mathrm{mg} / \mathrm{kg}$ choline as choline chloride. In both experiments, diets were based on white rice, soybean meal, and corn gluten. In Experiment I, birds fed choline chloride presented higher feed intake than those fed Biocholine ${ }^{\mathrm{TM}}$. Both choline supplements linearly improved feed conversion ratio (FCR) between 15 and $28 \mathrm{~d}$, but the curves presented different slopes, showing that one unit (U) of Biocholine ${ }^{\mathrm{TM}}$ was equivalent to $2.52 \mathrm{U}$ of choline supplied as choline chloride. In Experiment II, the supplementation of choline had a quadratic effect on weight gain (WG) but did not affect FCR. Choline requirements for WG were determined as 778,632 , and $645 \mathrm{mg} / \mathrm{kg}$ for $1-7,1-35$, and $1-42 \mathrm{~d}$ of age, respectively.
\end{abstract}

Keywords: bioequivalence; broiler; fatty liver; nutritional requirements; perosis.

\section{Resumo}

Dois experimentos foram conduzidos para avaliar a bioequivalência de uma fonte comercial de fosfatidilcolina (Biocholine ${ }^{\circledR}$ ) como alternativa ao cloreto de colina e as exigências de colina de frangos de rápido desempenho. No Experimento I, 672 frangos foram alimentados com quatro níveis de Biocholine ${ }^{\circledR}(0,100,200$ ou $300 \mathrm{mg} / \mathrm{kg})$ e três níveis de colina $(200,400$ ou $600 \mathrm{mg} / \mathrm{kg})$ supridas pelo cloreto de colina entre 4 e 28 dias de idade. No Experimento II, 462 frangos receberam dietas suplementadas com $0,200,400,600$ ou $800 \mathrm{mg} / \mathrm{kg}$ de colina através do cloreto de 
colina. Em ambos os experimentos, as dietas foram à base de arroz branco, farelo de soja e glúten de milho. No Experimento I, as aves alimentadas com cloreto de colina apresentaram maior consumo de ração em relação àquelas alimentadas com Biocholine ${ }^{\circledR}$. Ambas as fontes de colina melhoraram linearmente a conversão alimentar entre 15 e 28 dias, mas as curvas apresentaram diferentes inclinações, mostrando que uma unidade de Biocholine ${ }^{\circledR}$ foi equivalente a 2,52 unidades de colina suprida na forma de cloreto de colina. No Experimento II, a suplementação de colina apresentou efeito quadrático sobre o ganho de peso sem afetar a conversão alimentar. As exigências de colina para ganho de peso foram 778, 632 e $645 \mathrm{mg} / \mathrm{kg}$ para as fases de 1-7, 1-35 e 1-42 dias de idade, respectivamente.

Palavras-chave: bioequivalência; frango de corte; fígado gorduroso; exigência nutricional; perose.

Received on September $15^{\text {th }}, 2015$.

Accepted on February $7^{\text {th }}, 2017$.

\section{Introduction}

The nutrient choline has three essential metabolic functions: it is a component of membrane phospholipids $^{(1)}$; it participates in lipid liver metabolism, preventing fat accumulation in the liver ${ }^{(2)}$; and it is a precursor of acetylcholine ${ }^{(3)}$. In addition, choline prevents perosis or chondrodystrophy in poultry ${ }^{(4)}$, and it can be oxidized to betaine to donate methyl groups ${ }^{(5)}$, sharing this function with methionine, which, according to Zeisel ${ }^{(6)}$, consumes the most choline in the body. Studies have shown that the nutritional requirements of choline and methionine are interdependent, i.e., increasing the supply of one of these nutrients reduces the requirement of the other ${ }^{(7)}$. Similarly, higher dietary betaine levels reduce choline requirements ${ }^{(8)}$. Choline is present in the feedstuffs as free choline or in the form of complexes, including phosphocholine, glycerophosphocholine, sphingomyelin, or phosphatidylcholine ${ }^{(9)}$, which is the main form of choline in plant feedstuffs ${ }^{(10)}$. In the body, phosphatidylcholine is responsible for removing lipids from the liver as it is essential for the synthesis of very low-density lipids (VLDL) ${ }^{(11)}$, which transport fat to the peripheral tissues. Phosphatidylcholine also accounts for $35 \%$ of cell membrane phospholipids ${ }^{(1)}$.

Due to its importance, choline is commonly supplemented in broiler diets as choline chloride. However, this product is highly hygroscopic, and may result in losses of water-soluble vitamin added to premixes because it increases free water content in the mixture, resulting in higher reactive potential. In addition, this causes operational problems in the feed mill as the product may form lumps ${ }^{(12)}$.

Choline nutritional requirements of broilers are based on studies carried out decades ago ${ }^{(13,14)}$, and therefore, they need to be updated as there have been significant changes in diet formulation and particularly in bird performance since then. Waldroup et al. ${ }^{(15)}$ observed improvement in the Feed Convertion Rate (FCR) and in the breast yield to 42, 49, and 56 days with $1000 \mathrm{mg} / \mathrm{kg}$ of choline supplementation on a diet containing between 1193 (1 to 14 days) and $925 \mathrm{mg} / \mathrm{kg}$ of choline (42 to 56 day), without changing the Weight Gain (WG) and the carcass yield. Similar results were obtained by Pompeu et al. ${ }^{(16)}$, who observed a difference only for FCR at 21 days, with linear response for this variable with choline supplementation up to $400 \mathrm{mg} / \mathrm{kg}$ in a basal diet containing 
$1367 \mathrm{mg} / \mathrm{kg}$ of choline. Swain and Johri ${ }^{(17)}$ used a diet containing $1300 \mathrm{mg} / \mathrm{kg}$ of choline and found no effect of supplementation on performance at 42 days.

The objectives of this study were to evaluate the bioequivalence of a commercial phosphatidylcholine source (Biocholine ${ }^{\mathrm{TM}}$ ) as an alternative to choline chloride, and to determine choline requirements of broilers of a fast-growth strain. The incidence of perosis and fatty liver was also investigated.

\section{Material and Methods}

All the experimental procedures were approved by the Committee of Ethics on the Use of Animals of the Federal University of Rio Grande do Sul, under protocol No 24156.

Two experiments were performed. In experiment I, the bioequivalence between the commercial product Biocholine ${ }^{\mathrm{TM}}$ (phosphatidylcholine source, low-hygroscopicity plant extract based on Trachyspermum amni, Citrullus colocynthis, Achyranthus aspera, and Azadirachta indica) and choline chloride was evaluated. As none of the birds showed any deficiency symptoms at the choline levels employed, Experiment II was carried out to determine choline requirements of fastgrowing broilers.

In both experiments, birds were housed in an environmentally-controlled room in $1-\mathrm{m}^{2}$ pens on wood-shavings litter. Pens were equipped with nipple drinkers and tube feeders. Water and feed were supplied ad libitum. An artificial lighting program of 24.00 hours of light was adopted.

In Experiment I, 672 one-day-old male broilers were housed in 56 pens, at a density of 12 birds/pen, and in Experiment II, 462 one-day-old male broilers were housed in 42 pens, at a density of $11 \mathrm{birds} / \mathrm{pen}$. In both experiments, Cobb 500 ${ }^{\mathrm{TM}}$ broilers were used. Birds were vaccinated at the hatchery against Marek's disease, infectious bronchitis, fowl pox, and infectious bursal disease. At the start of the experimental period, birds were uniformly distributed in the pens according to body weight (average initial weight of $117 \pm 2,7 \mathrm{~g}$ in Experiment I and $47 \pm 1 \mathrm{~g}$ in Experiment II).

The following feeding phases were applied: 4-21 and 22-28 days (d) of age (Experiment I) and 121, 22-35, and 36-42 d of age (Experiment II). In both experiments, feedstuffs containing low choline levels were used in order to evaluate the effect of supplementation. Diets were based on white rice, corn gluten (600 g/kg crude protein), and gummed or de-gummed soybean meal in Experiments I and II, respectively (Table 1). Choline content of white rice was obtained from the USDA tables ${ }^{(10)}$; the content of soybean isolate protein was supplied by the manufacturer (Solae Company ${ }^{\mathrm{TM}}$ ), and of the remaining feedstuffs was obtained from the $\mathrm{NRC}$ for $\mathrm{pigs}^{(18)}$. Aiming at preventing severe choline deficiency symptoms in Experiment I, birds were fed up to four $\mathrm{d}$ of age a diet based on corn and soybean meal formulated to supply the nutritional levels proposed by Rostagno et al. ${ }^{(19)}$ for this phase. This diet contained $1300 \mathrm{mg} / \mathrm{kg}$ choline. As no choline deficiency symptoms were observed in Experiment I, choline values of the basal diets supplied in Experiment II were reduced by using soy protein isolate and de-gummed soybean meal. All experimental diets were supplied in the meal form and contained equal energy and nutrient levels calculated to supply the nutritional requirements proposed by Rostagno et al. ${ }^{(19)}$, except for choline. 
Table 1. Ingredient composition and nutritional levels of the experimental diets (on as-is basis)

\begin{tabular}{|c|c|c|c|c|c|}
\hline \multirow[b]{2}{*}{ Ingredients $(\mathrm{g} / \mathbf{k g})$} & \multicolumn{2}{|c|}{ Experiment I } & \multicolumn{3}{|c|}{ Experiment II } \\
\hline & $\begin{array}{c}\text { Starter } \\
4-21 \text { days }\end{array}$ & $\begin{array}{c}\text { Grower } \\
22-28 \text { days }\end{array}$ & $\begin{array}{c}\text { Starter } \\
1-21 \text { days }\end{array}$ & $\begin{array}{c}\text { Grower } \\
22-35 \text { days }\end{array}$ & $\begin{array}{c}\text { Finisher } \\
36-42 \text { days }\end{array}$ \\
\hline White rice & 632.7 & 634.5 & 644.3 & 696.4 & 720.7 \\
\hline Soybean meal $450 \mathrm{~g} / \mathrm{kg}^{\mathrm{l}}$ & 228.3 & 230.3 & 143.5 & 109.4 & 107.5 \\
\hline Corn gluten $600 \mathrm{~g} / \mathrm{kg}$ & 77.0 & 59.5 & 115.5 & 100.0 & 72.0 \\
\hline Soy protein isolate & - & - & 30.0 & 30.0 & 30.0 \\
\hline Soybean oil & 12.6 & 30.4 & 11.0 & 14.8 & 23.6 \\
\hline Limestone & 8.2 & 7.6 & 11.4 & 9.4 & 8.1 \\
\hline Dicalcium phosphate & 17.4 & 14.9 & 20.6 & 16.1 & 14.0 \\
\hline Salt & 4.8 & 4.6 & 1.0 & & \\
\hline L-lysine & 3.7 & 3.5 & 4.8 & 4.3 & 4.1 \\
\hline DL-methionine & 2.6 & 2.3 & 1.6 & 1.4 & 1.7 \\
\hline L-threonine & 1.2 & 0.9 & 0.8 & 0.7 & 0.9 \\
\hline Mineral premix ${ }^{2}$ & 1.0 & 1.0 & 0.7 & 0.7 & 0.7 \\
\hline Vitamin premix ${ }^{3}$ & 0.5 & 0.5 & 0.5 & 0.5 & 0.5 \\
\hline Na bicarbonate & - & - & 5.5 & 6.7 & 6.7 \\
\hline K chloride & - & - & 3.6 & 4.4 & 4.5 \\
\hline Monensin $400 \mathrm{~g} / \mathrm{kg}$ & - & - & 0.25 & 0.25 & 0.25 \\
\hline Corn starch ${ }^{4}$ & 10.0 & 10.0 & 5.0 & 5.0 & 5.0 \\
\hline \multicolumn{6}{|l|}{ Nutritional values } \\
\hline $\mathrm{ME}^{5}(\mathrm{kcal} / \mathrm{kg})$ & 3050 & 3150 & 3082 & 3150 & 3200 \\
\hline $\mathrm{CP}^{6}$, analyzed $(\mathrm{g} / \mathrm{kg})$ & 200.0 & 189.1 & 217.1 & 203.0 & 176.9 \\
\hline $\mathrm{Ca}(\mathrm{g} / \mathrm{kg})$ & 8.2 & 7.3 & 9.4 & 7.6 & 6.6 \\
\hline Available $P(\mathrm{~g} / \mathrm{kg})$ & 3.9 & 3.4 & 4.4 & 3.5 & 3.1 \\
\hline $\mathrm{Na}(\mathrm{g} / \mathrm{kg})$ & 2.1 & 2.0 & 2.4 & 2.3 & 2.3 \\
\hline Dig. Lys (g/kg) & 11.7 & 10.8 & 11.4 & 10.2 & 9.7 \\
\hline Dig. Met $(\mathrm{g} / \mathrm{kg})$ & 5.9 & 5.4 & 5.4 & 4.9 & 4.8 \\
\hline Dig. Met + Cys $(g / k g)$ & 8.5 & 7.9 & 8.2 & 7.4 & 7.1 \\
\hline Dig. Thr $(\mathrm{g} / \mathrm{kg})$ & 7.6 & 7.0 & 7.4 & 6.6 & 6.3 \\
\hline Dig. Trp $(\mathrm{g} / \mathrm{kg})$ & 2.1 & 2.1 & 2.1 & 1.9 & 1.8 \\
\hline Dig. Arg (g/kg) & 12.7 & 11.9 & 12.1 & 11.0 & 10.5 \\
\hline $\mathrm{DEB}^{7}(\mathrm{mEq} / \mathrm{kg})$ & 140 & 140 & 180 & 180 & 180 \\
\hline
\end{tabular}

${ }^{1}$ Gummed and de-gummed soybean meal in Experiments I and II, respectively.

${ }^{2}$ Composition (per kg): $150,000 \mathrm{mg} \mathrm{Mn} ; 100,000 \mathrm{mg} \mathrm{Zn;} 80,000 \mathrm{mg}$ Fe; $15,000 \mathrm{mg} \mathrm{Cu} ; 1,200 \mathrm{mg} \mathrm{I} ; 700 \mathrm{mg}$ Se.

${ }^{3}$ Composition (per kg): $23,200,000$ UI vitamin A; $5,600,000$ UI vitamin D; $52000 \mathrm{mg}$ vitamin $\mathrm{K} ; 6000 \mathrm{mg}$ vitamin B; $18,000 \mathrm{mg}$ vitamin $\mathrm{B}_{2} ; 9,000 \mathrm{mg}$ vitamin $\mathrm{B}_{6} ; 132,000 \mathrm{mg}$ niacin; $44,000 \mathrm{mg}$ pantothenic acid; $2,400 \mathrm{mg}$ folic acid, $200,000 \mu \mathrm{g}$ biotin; $40,000 \mu \mathrm{g}$ vitamin $\mathrm{B}_{12}$.

${ }^{4}$ In Experiment I: treatments with Biocholine ${ }^{\mathrm{TM}}(\mathrm{BC})-1 \%$ starch; $0.99 \%$ starch and $0.01 \% \mathrm{BC} ; 0.98 \%$ starch and $0.02 \%$ $\mathrm{BC} ; 0.97 \%$ starch and $0.03 \% \mathrm{BC}$ for $0,100,200$, and $300 \mathrm{mg} \mathrm{BC} / \mathrm{kg}$; treatments with choline chloride $(\mathrm{CL})-0.957 \%$ starch and $0.043 \% \mathrm{CL} ; 0.913 \%$ starch and $0.087 \% \mathrm{CL} ; 0.870 \%$ starch and $0.130 \% \mathrm{CL}$ for 200 , 400 , and $600 \mathrm{mg}$ choline/ $\mathrm{kg}$ supplied by $\mathrm{CL}$.

In Experiment II $0.5 \%$ starch; $0.041 \% \mathrm{CL}$ and $0.459 \%$ starch; $0.083 \% \mathrm{CL}$ and $0.417 \%$ starch; $0.123 \% \mathrm{CL}$ and $0.377 \%$ starch; $0.166 \% \mathrm{CL}$ and $0.334 \%$ starch for $0,200,400,600$, and $800 \mathrm{mg}$ choline $/ \mathrm{kg}$ supplied by CL.

${ }^{5}$ Metabolizable energy.

${ }^{6}$ Crude protein.

${ }^{7}$ Dietary electrolyte balance $(\mathrm{Na}+\mathrm{K}-\mathrm{Cl})$.

In Experiment I, seven treatments were applied, consisting of the comparison of four Biocholine ${ }^{\mathrm{TM}}$ levels $(0,100,200$, and $300 \mathrm{mg} / \mathrm{kg}$ ) with three choline levels $(200,400$, and $600 \mathrm{mg} / \mathrm{kg})$, with eight replicates per treatment. In Experiment II, five treatments, consisting of choline levels of 0, 200, 
400, 600, or $800 \mathrm{mg} / \mathrm{kg}$ diet, were applied, with eight replicates each, except for the level of 0 $\mathrm{mg} / \mathrm{kg}$, which had 10 replicates. The choline levels used in Experiment II were selected considering the calculated choline values of the basal diets, to include both the linear and the plateau section of the performance response curves, based on the study of Lima ${ }^{(7)}$, who found choline requirement between 872 and $1013 \mathrm{mg} / \mathrm{kg}$ for broilers from 1 to 21 days. Choline requirements were determined by calculating the maximum point of weight gain (WG) equations and considering the cumulative periods in order to prevent the interference of the previous treatment. In Experiment II, choline was supplemented as choline chloride at $600 \mathrm{~g} / \mathrm{kg}$, discounting the participation of chlorine, which accounts for $251.8 \mathrm{~g} / \mathrm{kg}$ of the molecule of choline chloride. In both experiments, choline supplements were included at the expense of corn starch. A single basal diet was manufactured for each phase into which the supplements were added.

The product Biocholine ${ }^{\mathrm{TM}}$, white rice, gummed and de-gummed soybean meal, corn gluten, and soy protein isolate were submitted to the Department of Nutrition of North Carolina University for the analysis of choline according to the methodology described by Koc et al. ${ }^{(20)}$. Choline chloride was analyzed by ion chromatography ${ }^{(21)}$. Crude protein content of the basal diets was determined according to the method No 984.13 of the AOAC ${ }^{(22)}$ adapted by Prates ${ }^{(23)}$.

Although in the report issued by the manufacturer Biocholine ${ }^{\mathrm{TM}}$ contains $16.7 \mathrm{~g} / \mathrm{kg}$ phosphatidylcholine, the analysis showed only $2.9 \mathrm{~g} / \mathrm{kg}$. The choline values analyzed in the diets of both experiments were also lower than those reported in feedstuff tables (Table 2). Dietary betaine content was also analyzed due to its choline-sparing effect ${ }^{(24)}$. However, the analysis results showed low betaine levels, and therefore, it is assumed that they did not influence choline requirements in the present study.

Table 2. Choline and betaine levels in the feedstuffs and in the experimental diets

\begin{tabular}{lcc}
\hline Item & $\begin{array}{c}\text { Choline, analyzed } \\
(\mathbf{m g} / \mathbf{k g})\end{array}$ & $\begin{array}{c}\text { Choline, calculated } \\
(\mathbf{m g} / \mathbf{k g})\end{array}$ \\
\hline White rice & 30 & 58 \\
Corn gluten & 141 & 330 \\
De-gummed soybean meal & 1593 & 2794 \\
Gummed soybean meal & 2267 & 2794 \\
Soy protein isolate & 1318 & 1110 \\
Starter diet, T1, Experiment $\mathrm{I}^{2}$ & 547 & 700 \\
Grower diet, T1, Experiment $\mathrm{I}^{2}$ & 549 & 700 \\
Starter diet, T1, Experiment $\mathrm{II}^{2}$ & 304 & 600 \\
Grower diet, T1, Experiment $\mathrm{II}^{2}$ & 249 & 510 \\
Finisher diet, T1, Experiment $\mathrm{II}^{2}$ & 243 & 500 \\
\hline${ }^{2}$ Values based on the tables of the NRC (1998), USDA (2008), and Solae Company ${ }^{\mathrm{TM}}$. & \\
${ }^{2}$ Formulation values based on choline and betaine values in the feedstuffs.
\end{tabular}

In both experiments, body weight (BW), feed intake (FI), and perosis incidence were weekly evaluated, and WG and feed conversion rate (FCR) corrected for mortality were calculated. Mortality and environmental temperature were daily measured.

At the end of the experiments, birds were euthanized by stunning using electronarcosis and jugular vein excision. Livers were then collected, immediately frozen at $-86{ }^{\circ} \mathrm{C}$ for subsequent freezedrying and ether extract (EE) determination by the method No 920.39 of the $\mathrm{AOAC}^{(22)}$. In 
Experiment I, one bird per replicate was euthanized, totaling 56 birds, and in Experiment II, five birds fed 0, 400, and $800 \mathrm{mg}$ choline/kg of diet were euthanized, totaling 15 birds.

Each experiment was individually analyzed using the software program Statgraphics Plus 5.1 ${ }^{\mathrm{TM}}$. Data were submitted to analysis of variance and analyses of regression for each choline source. In Experiment I, analyses of contrasts were performed (no choline supplementation vs. Biocholine ${ }^{\mathrm{TM}}$; no choline supplementation vs. choline chloride; and Biocholine ${ }^{\mathrm{TM}} v s$. choline chloride). When $\mathrm{F}$ was significant, means were compared by the LSD test.

\section{Results and Discussion}

The different forms of choline present in the feedstuffs (free choline, glycerophosphocholine, phosphocholine, phosphatidylcholine, and sphingomyelin) ${ }^{(9)}$ may hinder choline quantification and may explain differences in the results of analyses carried out in different laboratories as well as justify the differences between calculated and analyzed values obtained in the present study. For instance, white rice choline values varied between 58 and $1003 \mathrm{mg} / \mathrm{kg}$ depending on the table used $^{(10,18)}$. Therefore, we decided to apply analyzed values due to the variations in the nutritional composition of feedstuffs.

In both experiments, the mortality rate was as expected, below 3\%, and it was not influenced by choline sources or levels. In Experiment I, WG and FCR were not influenced by choline sources or levels in none of the studied phases, as determined by the analysis of variance (Table 3). However, the contrast analysis showed that Biocholine ${ }^{\mathrm{TM}}$ provided better FCR between 15 and $28 \mathrm{~d}$, when compared to birds that did not receive supplementation, proving to be an alternative for the reduction of production costs. Besides that, in the same period and during the total experimental period, birds supplemented with Biocholine ${ }^{\mathrm{TM}}$ presented lower FI in relation to choline chloride (Table 3).

While some researchers did not find any influence of choline supplementation on $\mathrm{FCR}^{(24,25)}$, other studies demonstrated that choline had a positive effect on this parameter ${ }^{(15,26,27)}$. This may be explained by differences in sulfur amino acid levels because choline did not affect FCR only in studies where diets contained high levels of these amino acids, as in the present study.

According to the regression analyses, which are used to compare choline sources, both supplements linearly improved FCR between 15 and 28 d (Table 5). However, the slopes of the equations were different $(\mathrm{P}<0.04$, Figure 1), and the ratio between angle coefficients showed that one unit of the product Biocholine ${ }^{\mathrm{TM}}$ was equivalent to 2.52 units of pure choline as supplied by choline chloride. Biocholine $^{\mathrm{TM}}$ is an alternative to choline chloride for dietary choline supplementation, as Normative Instruction No 46 of the Brazilian Ministry of Agriculture ${ }^{(28)}$ that regulates organic food production banned the use of vitamins obtained by chemical synthesis, such as choline chloride, since 2013. The knowledge on the bioequivalence of Biocholine ${ }^{\mathrm{TM}}$ allows it to be efficiently used in organic food production systems.

In the present study, birds fed Biocholine ${ }^{\mathrm{TM}}$, which is a phosphatidylcholine source, presented better FCR responses (Figure 1) compared with those fed choline chloride. These results are similar to the 
ones obtained by Rodelas et. al. ${ }^{(29)}$, which indicate that biocholine associated with herbal vitamins $\mathrm{C}$ and $\mathrm{E}$ supplementation enhanced the overall feed efficiency of the broilers between 8 and 42 days. Calderano et al. ${ }^{(30)}$ found no performance differences between the biocholine or choline chloride supplementation for broilers. According to Cheng et al. ${ }^{(31)}$, the bioavailability and utilization of different choline esters varies, which may explain the higher efficiency of phosphatidylcholine. In addition, choline in the form of chloride can be broken down by the intestinal flora, being transformed in trimethylamine and immediately excreted ${ }^{(32)}$. On the other hand, there is no ${ }^{(33)}$ or low ${ }^{(34)}$ degradation of phosphatidylcholine in the gastrointestinal tract.

Table 3. Performance of male broilers fed diets supplemented with different choline sources and levels (Experiment I)

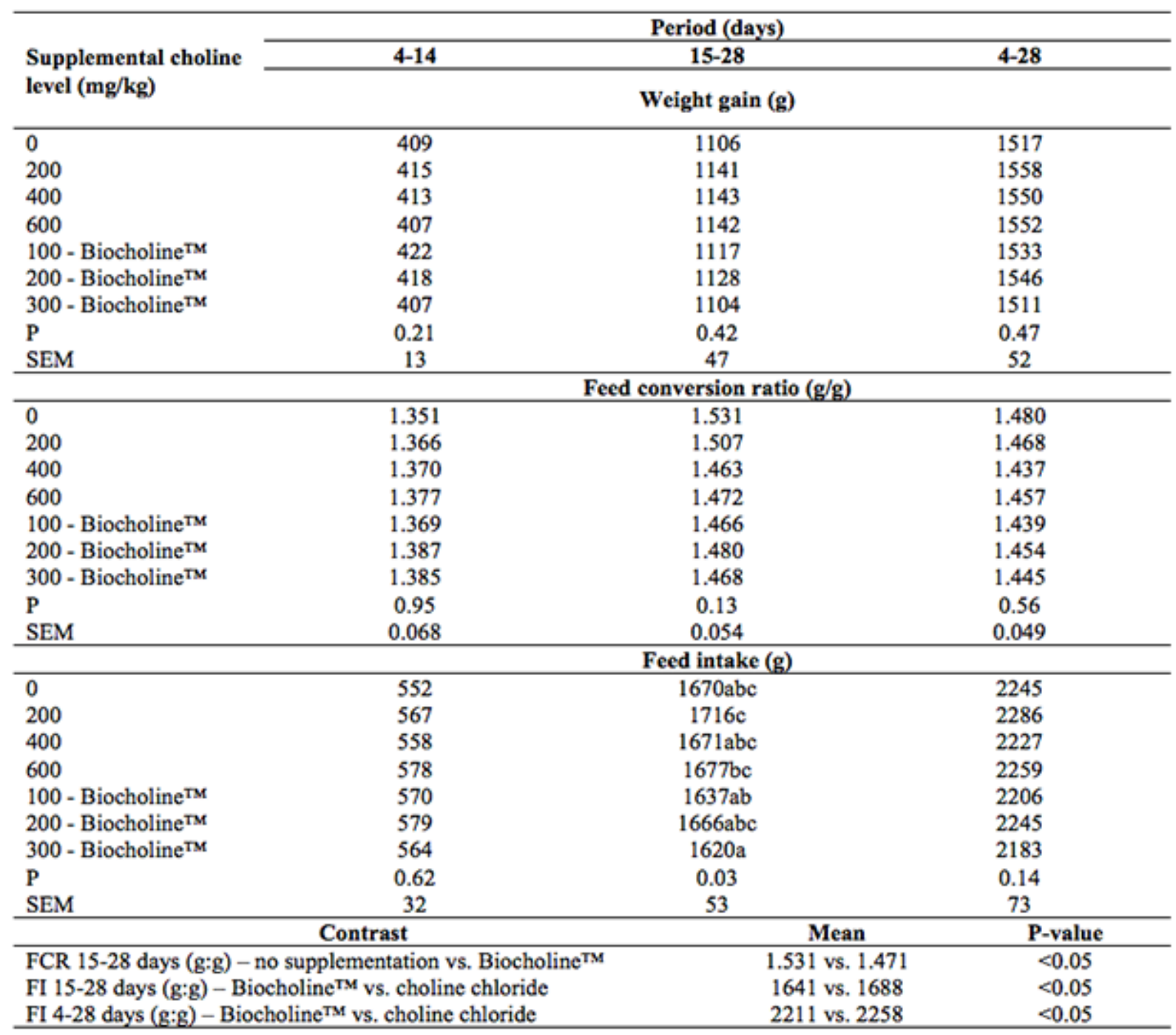

Means followed by different letters in the same column are statistically different by the LSD test at 0.05 probability level. Average initial weight (4 d): $117 \mathrm{~g}$. 
Table 4. Performance of male broilers fed diets supplemented with different choline levels (Experiment II)

\begin{tabular}{|c|c|c|c|c|}
\hline \multirow{3}{*}{ Supplemental choline level (mg/kg) } & \multicolumn{4}{|c|}{ Period (days) } \\
\hline & $1-7$ & $1-21$ & $1-35$ & $1-42$ \\
\hline & \multicolumn{4}{|c|}{ Weight gain (g) } \\
\hline 0 & 122 & 887 & 2202 & 2986 \\
\hline 200 & 132 & 942 & 2338 & 3105 \\
\hline 400 & 127 & 929 & 2295 & 3100 \\
\hline 600 & 127 & 898 & 2193 & 3000 \\
\hline 800 & 127 & 912 & 2233 & 3015 \\
\hline \multirow[t]{2}{*}{ SEM } & 8 & 44 & 91 & 91 \\
\hline & \multicolumn{4}{|c|}{ Feed conversion ratio $(\mathrm{g} / \mathrm{g})$} \\
\hline 0 & 1.256 & 1.307 & 1.459 & 1.523 \\
\hline 200 & 1.246 & 1.313 & 1.453 & 1.520 \\
\hline 400 & 1.253 & 1.302 & 1.444 & 1.510 \\
\hline 600 & 1.258 & 1.339 & 1.483 & 1.532 \\
\hline 800 & 1.301 & 1.324 & 1.466 & 1.523 \\
\hline \multirow[t]{2}{*}{ SEM } & 0.106 & 0.036 & 0.032 & 0.027 \\
\hline & \multicolumn{4}{|c|}{ Feed intake $(\mathrm{g})$} \\
\hline 0 & 154 & 1159 & 3209 & 4546 \\
\hline 200 & 164 & 1236 & 3396 & 4721 \\
\hline 400 & 163 & 1210 & 3312 & 4637 \\
\hline 600 & 159 & 1200 & 3249 & 4596 \\
\hline 800 & 165 & 1207 & 3273 & 4594 \\
\hline SEM & 11 & 52 & 123 & 151 \\
\hline
\end{tabular}

Average initial weight (1 day): $47 \mathrm{~g}$.

Table 5. Regression equations using calculated choline values (Experiment I)

\begin{tabular}{|c|c|c|c|}
\hline \multicolumn{4}{|l|}{ Parameter } \\
\hline & Equation & Effect & P-value \\
\hline$W^{1}, 4-14 d$ & For Biocholine $\mathrm{TM}^{\mathrm{M}}, \mathrm{Y}=409.698+0.1725 \times$ choline level $-0.0006 \times$ choline level ${ }^{2}, \mathrm{R}^{2}=0.192$ & Quadratic & 0.016 \\
\hline WG, $4-28 \mathrm{~d}$ & For Biocholine $\mathrm{TM}^{\mathrm{TM}}, \mathrm{Y}=1503.17+0.6117 \times$ choline level $-0.002 \times$ choline level ${ }^{2}, \mathrm{R}^{2}=0.185$ & Quadratic & 0.020 \\
\hline \multirow[t]{2}{*}{$\mathrm{FCR}^{2}, 15-28 \mathrm{~d}$} & For choline chloride, $\mathrm{Y}=1.6012-0.0001 \mathrm{x}$ choline level, $\mathrm{R}^{2}=0.147$ & Linear & 0.033 \\
\hline & For Biocholine $\mathrm{T}^{\mathrm{TM}}, \mathrm{Y}=1.5105-0.0002 \times$ choline level, $\mathrm{R}^{2}=0.157$ & Linear & 0.027 \\
\hline $\mathrm{FI}^{3}, 4-14 \mathrm{~d}$ & For Biocholine $\mathrm{TM}^{\mathrm{M}}, \mathrm{Y}=551.531+0.2878 \times$ choline level $-0.0008 \times$ choline level ${ }^{2}, \mathrm{R}^{2}=0.199$ & Quadratic & 0.028 \\
\hline FI, $15.28 \mathrm{~d}$ & For Biocholine ${ }^{\mathrm{TM}}, \mathrm{Y}=1681.16-0.184 \times$ choline level, $\mathrm{R}^{2}=0.129$ & Linear & 0.043 \\
\hline \multicolumn{4}{|c|}{$\begin{array}{l}\text { 1WG: Weight gain. } \\
\text { 2FCR: Feed conversion rate. } \\
{ }^{3} \text { FI: Feed intake. }\end{array}$} \\
\hline \multicolumn{4}{|l|}{ Parameter } \\
\hline $\mathrm{WG}^{1}, 1-7 \mathrm{~d}$ & $Y=106.669+0.0611 \times$ eholine level $-0.00004 \times$ choline level ${ }^{2}, R^{2}=0.133$ & Quadratic & 0.055 \\
\hline WG, $1-35 \mathrm{~d}$ & $\mathrm{Y}=2100.17+0.6018 \times$ eholine level $-0.0005 \times$ choline level ${ }^{2}, R^{2}=0.100$ & Quadratic & 0.053 \\
\hline WG, $1.42 \mathrm{~d}$ & $\mathrm{Y}=2858.31+0.6969 \times$ choline level $-0.0005 \times$ choline level ${ }^{2}, \mathrm{R}^{2}=0.128$ & Quadratic & 0.026 \\
\hline
\end{tabular}

'WG: Weight gain. 


\section{PLOT OF FITTED MODEL}

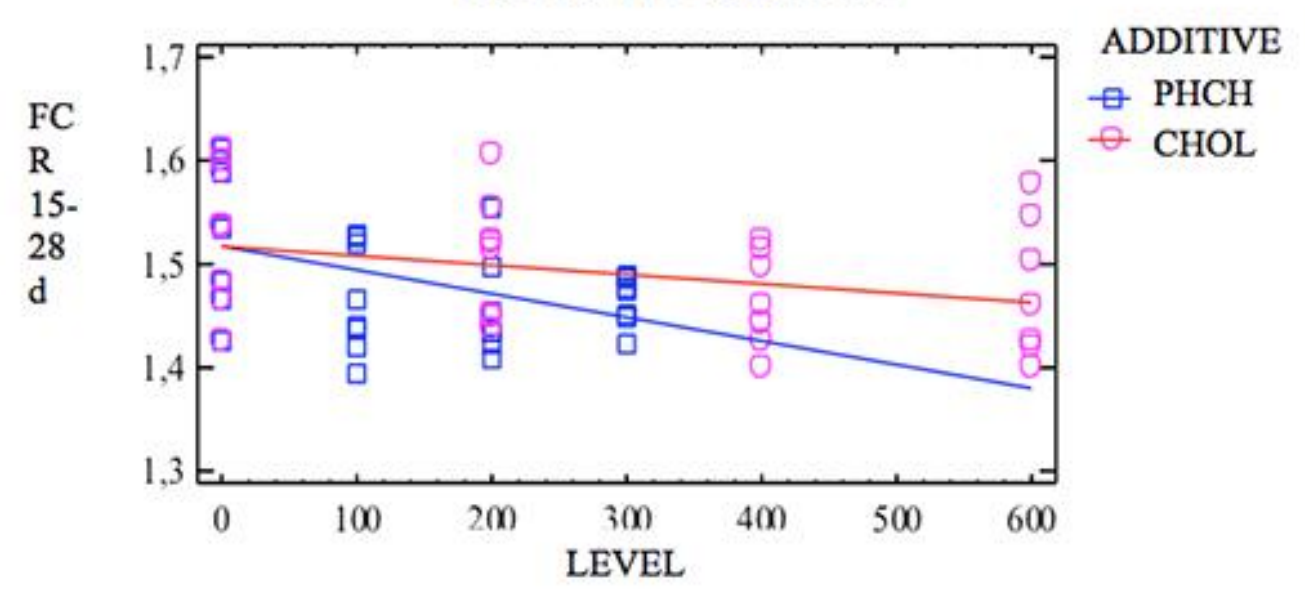

Equation for choline chloride: FCR 14 to 28 days $=1.51814-0.0000908354 \times$ choline level $(\mathrm{mg} / \mathrm{kg})(\mathrm{P}<0.02)$. Equation for Biocholine ${ }^{\mathrm{TM}}$ : FCR 14 to 28 days $=1.51814-0.000228921 \times$ Biocholine ${ }^{\mathrm{TM}}$ level $(\mathrm{P}<0.003) . \mathrm{R}^{2}=0.156$. PHCH: Biocholine ${ }^{\mathrm{TM}}$. CHOL: Choline chloride.

Figure 1. Comparison between Biocholine ${ }^{\mathrm{TM}}$ and choline chloride regression curves for feed conversion rate (FCR) during the period of 14-28 days (Experiment I).

The observed FCR improvement caused by Biocholine ${ }^{\mathrm{TM}}$ may be related to better dietary fat absorption. According to Rioux et al. ${ }^{(35)}$ and LeBlanc et al. ${ }^{(36)}$, the supplementation of phosphatidylcholine in the diet of rats increased bile juice flow, phosphatidylcholine content in the bile juice, and bile cholesterol content. These factors indicate that phosphatidylcholine has an indirect emulsifying role in fat digestion. Huang et al. ${ }^{(37)}$ observed that the replacement of $250 \mathrm{~g} / \mathrm{kg}$ soybean oil by soy lecithin improved fat digestibility in the starter phase and WG and FCR of oneto 42 -d-old broilers. Raber et al. ${ }^{(38)}$ verified that the inclusion of $5 \mathrm{~g} / \mathrm{kg}$ soy lecithin in broiler diets increased the percentage of dietary metabolizable fat. Zhang et al. ${ }^{(39)}$ demonstrated that the administration of lysophosphatidylcholine improved broiler WG in the starter phase and fatty acid digestibility and apparent metabolizable energy between 35 and $38 \mathrm{~d}$ of age.

In Experiment II, FCR and FI were not influenced by choline levels in none of the evaluated phases. On the other hand, choline supplementation caused quadratic effect in WG during 1-35 and 1-42 $(\mathrm{P}<0.05$, Table 6$)$. The absence of $\mathrm{WG}$ response in the first week may be attributed to the choline reserves in the yolk, which contains approximately $6800 \mathrm{mg}$ of choline $/ \mathrm{kg}^{(10)}$. Choline requirements for WG were determined as 778, 632, and $645 \mathrm{mg} / \mathrm{kg}$ for the ages of 1-7, 1-35, and 1-42 d, respectively (Table 6). These values are close to those obtained with purified diets, of $600^{(14,40)}$ to $720 \mathrm{mg} / \mathrm{kg}^{(8)}$, but much lower than those determined in studies using practical diets. The WG regression equation was not significant for the phase of 1-21 d, allowing us to conclude that the choline level of the basal diet was sufficient to supply the birds' requirements.

However, the regression equation for the period of 1-35 d shows that choline requirements increased after the third week. Viola et al. ${ }^{(41)}$ also observed higher nutritional requirements during the phase of 21-28 d in broilers, which was attributed by the authors to the high lean growth rate at this age. Pesti et al. ${ }^{(42)}$ supported the theory that performance parameters are not adequate to 
evaluate choline requirements in poultry because when choline-deficient diets are offered, birds utilize other sources, such as methionine, betaine, and cystine, to supply this deficiency. Studies have shown that when dietary choline level is increased, methionine requirement is reduced and vice versa, which is called the methionine-sparing effect $^{(7,26)}$. Studies using diets with low methionine levels (3.8 and $3.2 \mathrm{~g} / \mathrm{kg}$ ) determined choline requirements of $1200^{(14)}$ and 1910 $\mathrm{mg} / \mathrm{kg}^{(10)}$ in starter broilers.

Changes in the genetic potential should also be taken into account when comparing the nutritional requirements of broilers. In fast-growing poultry, the increase in muscle cell volume (hypertrophy) seems to be more important for growth than the increase in the number of cells (hyperplasia) ${ }^{(42)}$. Considering that the increase in internal volume in these cells is proportionally higher than the increase in cell surface membrane, and taking into account the participation of choline in cell membranes $^{(1)}$ as well as its role as precursor of acetylcholine ${ }^{(43)}$, it is plausible to suppose that choline requirements of broilers of different sizes is similar.

Broiler genetic improvement has focused on increasing both FI capacity and body growth rate. As modern broilers have high FI, their choline intake has also increased; therefore, their choline requirement per unit of WG may have decreased. In a recent study feeding diets based on corn and soy protein concentrate for Cobb $500^{\mathrm{TM}}$ broilers, choline requirement at standard methionine levels $\left(5.9 \mathrm{~g} / \mathrm{kg}\right.$ ) was determined as $1013 \mathrm{mg} / \mathrm{kg}$ for the period of $1-21 \mathrm{~d}$ of age ${ }^{(7)}$, which value is intermediate between the studies mentioned in this article and the present study. According to Briz and Pérez ${ }^{(44)}$, diets based on corn and soybean contain approximately $1350 \mathrm{mg}$ choline/kg and do not require supplementation ${ }^{(25)}$, even at low dietary methionine levels ${ }^{(17)}$.

There was no difference $(\mathrm{P}>0.05)$ in liver fat percentage among choline sources or levels in none of the experiments. Average fat values determined on dry matter basis were $176.8 \mathrm{~g} / \mathrm{kg}$ (experiment I) and $177.7 \mathrm{~g} / \mathrm{kg}$ (experiment II), and are consistent with those reported in literature ${ }^{(16)}$. Fatty liver is caused by the lack of methyl groups in the diet, and not merely by choline deficiency ${ }^{(45)}$. The supply of methyl groups was adequate in the present study because the diet contained adequate methionine levels, and due to the dietary inclusion of soybean meal and corn gluten, which contain the molecule S-methylmethionine (SMM) that is analogous to S-adenosylmethionine ${ }^{(46)}$. Lipstein et al. ${ }^{(47)}$ found that broilers fed practical (1942 mg choline/kg) and semi-purified (268 mg choline/kg) diets presented similar lipid deposition in the liver.

No symptoms of perosis were observed in none of the experiments. The results of literature studies on the effect of choline on perosis are contradictory. Pesti et al. ${ }^{(48)}$ fed broilers a basal diet with no choline and $4.3 \mathrm{~g} / \mathrm{kg}$ methionine and found high incidence of perosis when the diet was supplemented with 150-600 mg choline/kg. According to Fritz et al. ${ }^{(49)}, 1900 \mathrm{mg}$ choline/kg of diet are required to prevent that disorder. On the other hand, a study demonstrated that $450 \mathrm{mg}$ choline/kg can dramatically reduce perosis ${ }^{(47)}$ in broilers, and Ryu et al. ${ }^{(50)}$, using a diet containing $750 \mathrm{mg}$ choline/ $\mathrm{kg}$ did not observe any signs of perosis in broilers up to $18 \mathrm{~d}$ of age. Manganese deficiency also causes perosis in broilers ${ }^{(51)}$, but in all the studies mentioned above, Manganese dietary levels were adequate. Other factors, in addition of the deficiency of those nutrients, may influence the incidence of perosis in broilers. For instance, Rizk et al. ${ }^{(52)}$ demonstrated that broilers reared on litter showed lower incidence of perosis than those reared in battery cages. 


\section{Conclusions}

Comparing regression curves for feed conversion rate (FCR) during the period of 14-28 days, the utilization of the product Biocholine ${ }^{\mathrm{TM}}$ improved this variable compared with choline chloride. Based on this response, the calculated equivalence between these two products is one unit of Biocholine $^{\mathrm{TM}}$ for 2.52 units of choline supplied as chloride (Experiment I).

The supplementation of choline chloride has a quadratic effect on WG, but did not influence FCR (Experiment II). Choline requirements for WG, based on the analyzed choline content of feedstuffs, is 778,632 , and $645 \mathrm{mg} / \mathrm{kg}$ for the phases of 1-7, 1-35, and 1-42 $\mathrm{d}$ of age, respectively.

Dietary choline levels of $304 \mathrm{mg} / \mathrm{kg}$ in the starter phase, $249 \mathrm{mg} / \mathrm{kg}$ in the grower phase, and 243 $\mathrm{mg} / \mathrm{kg}$ in the finisher phase do not cause perosis or fatty liver in broilers (Experiment II).

\section{Akcnoledgements}

The authors thank Technofeed Ltd. and CNPq (Conselho Nacional de Desenvolvimento Científico e Tecnológico) for the financial support to conduct this project. Also thank the Nutrition Research Institute (University of North Carolina at Chapel Hill) for choline analyzes.

\section{References}

1. Battaglia KB, Schimmel RJ. Cell membrane lipid composition and distribution: implications for cell function and lessons learned from photoreceptors and platelets. J Exp Biol. 1997;200:2927-36.

2. Best CH, Hershey JM, Huntsman M. The effect of lecithine on fat deposition in the liver of the normal rat. J Physiol. 1932;75:56-66.

3. Dale HH, Dudley HW. The presence of histamine and acetylcholine in the spleen of the ox and the horse. J Physiol. 1929;68:97-123.

4. Jukes TH. Prevention of perosis by choline. J Biol Chem. 1940;134:789-90.

5. du Vigneaud V, Chandler JP, Moyer AW, Keppel DM. The effect of choline on the ability of homocystine to replace methionine in the diet. J Biol Chem. 1939;131:57-76.

6. Zeisel SH. Choline deficiency. J Nutr Biochem. 1990;1:332-49.

7. Lima MB. Modelos matemáticos para predição das exigências da colina para frangos de corte [dissertation]. Piracicaba (SP): Universidade de São Paulo; 2012. Portuguese. Available from: http://www.teses.usp.br/teses/disponiveis/11/11139/tde-16082012-103634/pt-br.php.

8. Dilger RN, Garrow TA, Baker DH. Betaine can partially spare choline in chicks but only when added to diets containing a minimal level of choline. J Nutr. 2007;137:2224-8.

9. Zeisel SH, Mar M, Howe JC, Holden JM. Concentrations of choline-containing compounds and betaine in common foods. J Nutr. 2003;133:1302-7. 
10. National Nutrient Database for Standard Reference [Internet]. Beltsville (MD): United States Department of Agriculture - USDA, Agricultural Research Service; 2008 [modified 2008 mar 4; cited 2015 jul 15]. Available from: http://www.ars.usda.gov/SP2UserFiles/Place/80400525/Data/Choline/Choln02.pdf.

11. Yao Z, Vance DE. The active synthesis of phosphatidylcholine is required for very low density lipoprotein secretion from rat hepatocy. J Biol Chem. 1988;263:2998-3004.

12. Albers N, Gotterbarm G, Heimbeck W, Keller T, Seehawer J, Tran TD. Vitamins in animal nutrition. 1st ed. Arbeitsgemeinschaft für Wirkstoffe in der Tierernährung e.V., editor. Clenze: Agrimedia; 2002.

13. Pesti GM, Harper, AE, Sunde ML. Choline/methionine nutrition of starting broiler chicks. Three models for estimating the choline requirement with economic considerations. Poult Sci 1980. 59:1073-81.

14. Baker DH, Halpin KM, Czarnecki GL, Parsons CM. The choline-methionine interrelationship for growth of the chick. Poult Sci. 1982;62:133-7.

15. Waldroup PW, Motl MA, Yan F, Fritts CA. Effects of betaine and choline on response to methionine supplementation to broiler diets formulated to industry standards. J Appl Poult Res. 2006;15:58-71.

16. Pompeu MA, Lara LJC, Baião NC, Ecco R, Cançado SV, Rocha JSR, et al. [Levels of supplementation of choline in diets for male broilers in initial phase]. Arq Bras Med Vet Zootec. 2011;63:1446-52. Portuguese.

17. Swain BK, Johri TS. Effect of supplemental methionine, choline and their combinations on the performance and immune response of broilers. Br Poult Sci. 2000;41:83-8.

18. National Research Council - NRC (US). Nutrient Requirements of Swine. 10th rev. ed. Washington: The National Academies Press; 1998.

19. Rostagno HS, Albino LFT, Donzele JL, Gomes PC, Oliveira RF, Lopes DC, et al. Tabelas brasileiras para aves e suínos: Composição de alimentos e exigências nutricionais. 3rd ed. Rostagno HS, ed. Viçosa (MG): UFV, DZO; 2011. 252 p. Portuguese.

20. Koc H, Mar MH, Ranasinghe A, Swenberg JA, Zeisel SH. Quantitation of choline and its metabolits in tissues and foods by liquid chromatography/electrospray ionization-isotope dilution mass spectrometry. Analyt Chem. 2002;74:4734-40.

21. Wollard DC, Indyk HE. Determination of choline in milk and infant formulas by enzymatic analysis: collaborative study. J AOAC Int. 2000;83:131-8.

22. Association of Official Analytical Chemistry - AOAC. Official methods of analysis. 16th ed. Washington: AOAC International; 1995.

23. Prates ER. Técnicas de pesquisa em nutrição animal. 1st ed. Porto alegre: UFRGS; 2007. 414 p. Portuguese.

24. Hassan RA, Attia YA, EL-Ganzory EH. Growth, carcass quality and serum constituents of slow growing chicks as affected by betaine addition to diets containing 1. different levels of choline. Int $\mathrm{J}$ Poult Sci. 2005;4:840-50.

25. Waldroup PW, Fritts CA. Evaluation of separate and combined effects of choline and betaine in diets for male broilers. Int J Poult Sci. 2005;4:442-8.

26. Derilo YL, Balnave D. The choline and sulphur amino acid requeriments of broiler chickens fed on semipurified diets. Br Poult Sci. 1980;21:479-87.

27. Blair ME, Potter LM, Bliss BA, Shelton JR. Methionine, Choline, and sulfate supplementation of practical-type diets for young turkeys. Poult Sci. 1986;65:130-7. 
28. Brasil. Ministério da Agricultura, Pecuária e Abastecimento. Instrução Normativa no. 46 de 06 de outubro de 2011. Estabelece o Regulamento Técnico para os Sistemas Orgânicos de Produção Animal e Vegetal, bem como as listas de Substâncias Permitidas para uso nos Sistemas Orgânicos de Produção Animal e Vegetal. Portuguese. Available from: http://sistemasweb.agricultura.gov.br/sislegis/action/detalhaAto.do?method=consultarLegislacaoFederal.

29. Rodelas APM, Magpantay VA, Luis ES. Efficacy of biocholine alone or in combination with herbal vitamins C and E on the growth performance of broilers. Phillipp J Vet Anim Sci. 2011;37:19-26.

30. Calderano AA, Nunes RV, Rodrigueiro RJB, César RA. Replacement of choline chloride by a vegetal source of choline in diets for broilers. Cienc Anim Bras. 2015;16:37-44.

31. Cheng W, Holmes-McNary MQ, Mar M, Lien EL, Zeisel SH. Bioavailability of choline and choline esters from milk in rat pups. J Nutr Biochem. 1996;7:457-64.

32. Craciun S, Balskus EP. Microbial conversion of choline to trimethylamine requires a glycyl radical enzyme. Proc Natl Acad Sci U S A. 2012;109:21307-12.

33. Zeisel SH, Dacosta KA, Youssef M, Hensey S. Conversion of dietary choline to trimethylamine and dimethylamine in rats: dose-response relationship. J Nutr. 1989;119:800-4.

34. McDowell LR. Vitamins in animal and human nutrition. 2nd ed. Ames: Iowa State University Press; 2000. $793 \mathrm{p}$.

35. Rioux F, Perea A, Yousef IM, Lévy É, Malli L, Carrillo MC, Tuchweber B. Short-term feeding of a diet enriched in phospholipids increases bile formation and the bile acid transport maximum in rats. Biochim et Biophys Acta. 1994;1214:193-202.

36. LeBlanc M, Gavino V, Peréa A, Yousef IM, Lévy É, Tuchweber B. The role of dietary choline in the beneficial efects of lecithin on the secretion of biliary lipids in rats. Biochim Biophys Acta. 1998;1393:223234.

37. Huang J, Yang D, Wang T. Effects of replacing soy-oil with soy-lecithin on growth performance, nutrient utilization and serum parameters of broilers fed corn-based diets. Asian-Aust. J. Anim. Sci. 2007;20:1880-1886.

38. Raber MR, Ribeiro AML, Kessler, AM, Arnaiz V. [Supplementation of glycerol or lecithin in different levels of free fat acids in broiler diets]. Cienc Anim Bras. 2009;10:745-53. Portuguese.

39. Zhang B, Haitao L, Zhao D, Guo Y, Barri A. Effect of fat type and lysophosphatidylcholine addition to broiler diets on performance, apparent digestibility of fatty acids, and apparent metabolizable energy content. Anim Feed Sci Technol. 2011;163:177-84.

40. Molitoris BA, Baker DH. Assessment of the quantity of biologically available choline in soybean meal. J Anim Sci. 1976;42:481-9.

41. Viola TH, Ribeiro AML, Neto CB, Kessler AM. [Total and digestible amino acids formulation in diets with decreasing levels of crude protein for broilers from 21 to 42 days of age]. Rev Bras Zootec. 2008;37:303-10. Portuguese.

42. Smith JH. Relation of body size to muscle cell size and number in the chicken. Poult Sci. 1963;42:28390 .

43. Wauben PM, Wainwright PE. The influence of neonatal nutrition on behavioral development: a critical appraisal. Nutr Rev. 1999;57:35-44.

44. Briz RC, Pérez AB. Optimim vitamin nutrition in broilers and turkeys. In: Barroeta AC, Baucells MD, Pérez AB, Calsamiglia S, Casals R, Briz RC, Davin R et al., editors. Optimum vitamin level in the 
production of quality animal foods. Sheffield: 5M; 2012. p. 139-242.

45. Cook RJ, Horne DW, Wagner A. Effect of dietary methyl group deficiency on one-carbon metabolism in rats. J Nutr. 1989;119:612-7.

46. Augspurger NR, Scherer CS, Garrow TA, Baker DH. Dietary S-methylmethionine, a component of foods, has choline-sparing activity in chickens. J Nutr. 2005;135:1712-7.

47. Lipstein B, Bornstein S, Budowski P. Utilization of choline from crude soybean lecithin by chicks. 1 . Growth and prevention of perosis. Poul Sci. 1977;56:331-6.

48. Pesti GM, Benevenga NJ, Harper AE, Sunde ML. Factors influencing the assessment of the availability of choline in feedstuffs. Poult Sci. 1981;60:188-96.

49. Fritz JC, Roberts T, Boehne JW. The chick's response to choline and its application to an assay for choline in feedstuffs. Poult Sci. 1967;46:1447-54.

50. Ryu KS, Roberson KD, Pesti GM. The folic acid requirements of starting broiler chicks fed diets based on practical ingredients. 1. Interrelationships with dietary choline. Poult Sci. 1995;74:1447-55.

51. Settle EA, Mraz FR, Douglas CR, Bletner JK. Effect of diet and Manganese level on growth, perosis and ${ }^{54} \mathrm{Mn}$ uptake in chicks. J Nutr. 1969;97:141-6.

52. Rizk SW, Stake PE, Simmons RW. Curled toes and perosis-like abnormalities in cage reared broilers. Poult Sci. 1980;59:308-15. 